\title{
SISTEM PENGELOLAAN ASET TETAP PADA SEKRETARIAT DAERAH KABUPATEN BUTON
}

\author{
Waode Adriani Hasan \\ Program Studi Akuntansi, Fakultas Ekonomi \\ Universitas Muhammadiyah Buton, Baubau, Indonesia \\ e-mail: adriani.hasan@umbuton.ac.id
}

\begin{abstract}
ABSTRAK
Sebagai aset yang digunakan untuk mendukung operasional kegiatan pemerintah daerah, pengelolaan aset tetap harus dilaksanakan dengan asas fungsional, kepastian hukum, transparansi, efisiensi, akuntabilitas, serta asas kepastian nilai. Selain memperhatikan asas-asas pengelolaan, pemerintah juga harus memperhatikan manajemen aset tetap. Manajemen aset ialah proses mengelola biaya modal aset (capital asset) pemerintah daerah secarah efektif, termasuk analisis siklus hidup dan kapasitas masingmasing aset serta mengelola informasi tentang kebutuhan pemeliharaan, tingkat layanan aset dan kebutuhan akan aset baru. Penelitian ini adalah penelitian kualitatif dengan metode analisis data adalah deskriptif kualitatif. Hasil penelitian menunjukkan bahwa pengelolaan aset tetap pada Sekretariat Daerah Kabupaten Buton telah dilakukan dengan berpedoman Peraturan Menteri Dalam Negeri Nomor 19 Tahun 2016 tentang Pedoman Pengelolaan Barang Milik Daerah.
\end{abstract}

Kata Kunci: Aset Tetap, Sistem, Pengelolaan Aset

\section{ABSTRACT}

As an asset used to support the operations of local government activities, fixed asset management must be carried out with principles such as functional, legal certainty, transparency, efficiency, accountability, and the principle of value certainty. In addition to paying attention to management principles, the government must also pay attention to the management of fixed assets. Asset management is the process of managing a local government's capital assets cost effectively. It involves analyzing the lifecycle and capacity of each asset and developing information on maintenance requirements, service levels and new asset needs. This research is a qualitative research with data analysis method is descriptive qualitative. The results of the study show that the management of fixed assets in the Buton Regional Secretariat has been carried out with the guidance of the Minister of Home Affairs Regulation No. 19 of 2016 concerning Guidelines for the Management of Regional Property.

Keywords: Fixed Assets, Systems, Asset Management

\section{PENDAHULUAN}

Organisasi yang telah maju akan berusaha untuk memiliki sarana dan prasarana yang memadai untuk mencapai tujuan perusahaan, baik yang bersifat jangka pendek maupun jangka panjang. Untuk mencapai tujuan tersebut perusahaan harus memiliki aset yang dapat menjamin kelancaran operasional rutin perusahaan. Salah satu jenis aset yang dapat mendukung kelancaran operasional perusahaan ialah aset tetap. Aset tetap adalah 
aset berwujud yang dimiliki untuk digunakan dalam produksi atau penyediaan barang atau jasa, untuk direntalkan kepada pihak lain, atau untuk tujuan administratif; dan diharapkan untuk digunakan selama lebih dari satu periode [1].

Didalam pencatatan akuntansi aset tetap ada beberapa tahapan yang harus diperhatikan diantaranya saat pengakuan serta pengukuran, dan penilaian awal aset tetap. Aset tetap diakui pada saat manfaat ekonomik masa depan dapat diperoleh dan nilainya dapat diukur dengan handal [2]. Aset tetap harus diakui sebesar nilai/biaya perolehan. Biaya perolehan aset tetap meliputi (1)harga perolehannya, termasuk bea impor \& pajak pembelian; (2) biaya-biaya yang dapat diatribusikan secara langsung untuk membawa aset ke lokasi \& kondisi yang diinginkan agar aset siap untuk digunakan; dan (3) estimasi awal biaya pembongkaran \& pemindahan aset tetap [3].

Seiring dengan berjalannya waktu aset tetap akan mengalami kerusakan atau penurunan manfaat. Oleh sebab itu penyajian aset tetap di dalam laporan keuangan harus berdasarkan nilai wajar, yaitu nilai aset tetap neto setelah dikurangi biaya penyusutan dan rugi penurunan nilai aset tetap [4]. Penyusutan ialah pengakuan atas pengkonsumsian manfaat suatu aset atau berlalunya waktu yang membuat suatu aset menjadi usang atau rusak [5]. Untuk dapat menyajikan nilai wajar aset tetap, perusahaan terlebih dahulu harus membuat kebijakan terkait penyusutan aset tetap. Terdapat tiga hal yang harus dipertimbangkan oleh perusahaan dalam mengalokasikan nilai aset tetap sebagai biaya penyusutan, yaitu: biaya perolehan aset tetap; nilai sisa (residu); dan taksiran masa manfaat aset [3].

Pengelolaan aset bagi perusahaan dapat dilakukan melalui pencatatan aset, pembukuan, dan pelaporan dan yang lebih utama adalah pemanfaatan aset sesuai dengan kebutuhan perusahaan sehingga aset yang dimiliki oleh perusahaan dapat memberikan manfaat yang baik bagi perusahaan dalam melaksanakan aktifitas organisasi. Begitu pula dengan pengelolaan aset tetap di sektor pemerintahan. Sebagai aset yang digunakan untuk mendukung operasional kegiatan pemerintah daerah, pengelolaan aset harus dilaksanakan dengan asas fungsional, kepastian hukum, transparansi, efisiensi, akuntabilitas, serta asas kepastian nilai [6].

Dengan memperhatikan asas-asas dalam pengelolaan aset tetap maka perolehan aset dapat dilakukan secara efektif, efisien, serta memberikan nilai tambah bagi pemerintah daerah dalam melaksanakan fungsi dan tugasnya. Selain memperhatikan asas-asas pengelolaan, pemerintah daerah juga harus memperhatikan manajemen aset 
tetap. Manajemen aset ialah proses mengelola biaya modal aset (capital asset) pemerintah daerah secarah efektif, termasuk analisis siklus hidup dan kapasitas masingmasing aset serta mengelola informasi tentang kebutuhan pemeliharaan, tingkat layanan aset dan kebutuhan akan aset baru [7].

Manajemen aset yang baik akan dapat meningkatkan kinerja aset, kinerja lembaga pemerintah serta memberikan dukungan untuk membiayai pembangunan daerah. Seluruh aktifitas yang berkaitan dengan aset harus dapat diukur. Untuk itu pengukuran implementasi pengelolaan aset tetap sebagai fasilitas negara bertujuan untuk menilai keberhasilan atau kegagalan manfaat dari aset tetap, bagaimana mencapai tujuan dan sasaran yang ditetapkan, atau apakah aset tetap efektif dan efisien dalam mewujudkan visi dan misi pemerintah [8].

Sekretariat Daerah Kabupaten Buton merupakan salah satu satuan kerja yang memiliki aset yang dapat dimanfaatkan untuk menunjang kinerja sekretariat daerah dalam melaksanakan dan menjalankan setiap kegiatan operasional sehingga dapat memberikan manfaat yang baik bagi perkembangan dan pembangunan daerah untuk mencapai masyarakat yang maju sesuai dengan tujuan pemerintah daerah. Dengan pengelolaan aset yang baik maka sekretariat daerah Kabupaten Buton dapat melaksanakan aktifitas organisasi dengan baik dan efektif sehingga dapat memberikan nilai tambah bagi organisasi dalam upaya untuk meningkatkan kinerja pelayanannya. Berdasarkan uraian di atas, maka pertanyaan penelitian yang diajukan ialah "bagaimana sistem pengelolaan aset tetap pada Sekretariat Daerah Kabupaten Buton”.

\section{METODE PENELITIAN}

Menurut Indriantoro bahwa populasi adalah sekelompok orang, kejadian atau segala sesuatu yang mempunyai karakteristik tertentu.Sedangkan sampel adalah sebagian dari elemen-elemen populasi yang akan diteliti [9].Adapun yang menjadi populasi dalam penelitian ini adalah seluruh dokumen yang dimiliki Sekretariat Daerah Kabupaten Buton. Sedangkan sampel dari penelitian ini adalah seluruh dokumen aset tetap yang dimiliki Sekretariat Daerah Kabupaten Buton tahun 2017.

Teknik pengumpulan data yang digunakan yaitu wawancara dan dokumentasi. Wawancara yang dilakukan dengan pihak sekretariat daerah Kabupaten Buton tentang pengelolaan aset tetap.Dokumentasi adalah menelusuri dokumen-dokumen berkaitan dengan pengelolaan aset tetap sekretariat daerah Kabupaten Buton. 
Analisis data dalam penelitian ini adalah deskriptif kualitatif. Datadan informasi yang diperoleh dariSekretariat Daerah Kabupaten Buton berupa pengelolaan aset tetap serta data dokumentasi lainnya ditabulasikan dalam bentuk tabel kemudian diuraikan dalam bentuk kata untuk mejelaskan pengelolaan aset sehingga didapatkan gambaran jelas tentang pengelolaan aset tetap pada Sekretariat Daerah Kabupaten Buton.

\section{HASIL DAN PEMBAHASAN}

\section{a. Hasil Penelitian}

Berdasarkan hasil penelitian yang dilasanakan pada Sekretariat Daerah Kabupaten Buton maka dapat diuraikan sebagai berikut:

1) Jenis Aset Sekretariat Daerah Kabupaten Buton

Jenis aset yang terdapat pada sekretariat daerah kabupaten Buton adalah sebagai berikut :

1. Tanah

Tanah merupakan aset tetap yang dimiliki oleh sekretarian daerah kabupaten Buton yang perolehannya menggunakan anggaran dan belanja sekretariat daerah kabupaten Buton. Untuk pencatatan aset tanah bendahara pengurus/penyimpan barang sekretariat daerah kabupaten Buton mencatatnya dalam Kartu Inventaris Barang (KIB) A.

2. Peralatan dan Mesin

Peralatan dan mesin adalah jenis barang yang dimiliki oleh sekretariat daerah kabupaten Buton yang perolehannya menggunakan anggaran dan pendapatan belanja sekretariat daerah seperti mobil, motor, mesin pemotong rumput, AC, komputer, laptop, scanner, server, printer dan lain sebagainya.

Untuk pencatatan peralatan dan mesin bendahara pengurus/penyimpan barang sekretariat daerah kabupaten Buton mencatatnya dalam Kartu Inventaris Barang B (KIB B).

3. Gedung dan Bangunan

Gedung dan bangunan adalah barang milik sekretariat daerah yang menggunakan anggaran belanja sekretariat daerah dalam pembangunan maupun pengadaannya, seperti pembangunan kantor, rehabilitasi ringan atau berat bangunan kantor, sarana parkir, bangunan rumah dinas, pembangunan pagar rumah dinas dan lain sebagainya. 
Untuk pencatatan gedung dan bangunan bendahara pengurus/penyimpan barang sekretariat daerah mencatatanya dalam Kartu Inventaris Barang C (KIB C).

4. Jalan, Irigasi dan Jaringan

Jalan, irigasi dan jaringan adalah barang milik daerah yang terdapat pada sekretariat daerah kabupaten Buton yang perolehannya menggunakan anggaran pendapatan dan belanja yang terdapat pada sekretariat daerah, seperti jaringan air, sumur bor, instalasi listrik, genset dan lain sebagainya.

Untuk pencatatan barang milik daerah yang terdapat pada sekretariat daerah kabupaten Buton bendahara pengurus/penyimpan barang mencatatnya dalam Kartu Inventaris Barang D (KIB D).

2) Macam-Macam Perolehan Barang Milik Daerah

Adapun macam-macam perolehan barang milik daerah pada sekretarait daerah kabupaten Buton dapat dijelaskan sebagai berikut :

1) Lelang Terbuka

Proses lelang dilaksanakan sekretariat daerah kabupaten Buton jika nilai barang yang akan dibeli diatas Rp. 100.000.000,-. Dalam lelang terbuka ini pihak sekretariat daerah mengumumkan secara resmi melalui papan pengumuman, atau koran lokal.

2) Penunjukkan Langsung

Penunjukkan langsung dapat dilaksanakan oleh pihak sekretariat daerah dalam pengadaan barang milik daerah pada sekretariat daerah jika nilai barang yang akan dibeli dibawah Rp. 100.000.000,--

\section{b. Pembahasan}

Pengelolaan aset tetap pada dasarnya dilakukan untuk menghasilkan informasi yang andal dalam pelaporan keuangan pemerintah daerah, sebagai upaya meningkatkan efisiensi, efektivitas, dan nilai tambah dalam pengelolaannya. Aset tetap memiliki peran penting sebagai penunjang kegiatan pemerintah daerah untuk menjalankan tugas dalam memberikan pelayanan kepada masyarakat. Pengelolaan atas aset tetap yang dikelola oleh pemerintah daerah telah diatur oleh Pemerintah Pusat dalam berbagai peraturan yang paling umum digunakan diantaranya Peraturan Pemerintah Nomor 27 Tahun 2014 tentang Pengelolaan Barang Milik Negara/Daerah disertai pedoman teknisnya dalam Permendagri Nomor 19 Tahun 2016. 
Dalam pengelolaan aset, Sekretariat Daerah Kabupaten Buton berpedoman pada Permendagri Nomor 19 Tahun 2016, dengan memperhatikan asas-asas berikut ini.

a. Asas fungsional, yaitu pengambilan keputusan dan pemecahan masalahmasalahdibidang pengelolaan barang milik daerah yang dilaksanakan olehKuasa Pengguna Barang, Pengguna Barang, Pengelola Barang sekretariat Kabupaten Buton sesuai fungsi, wewenang, dan tanggung jawab masing-masing;

b. Asas kepastian hukum, yaitu pengelolaan barang milik daerah harusdilaksanakan berdasarkan hukum dan peraturan perundang-undangan;

c. Asas transparansi, yaitu pengelolaan barang milik daerah harus transaparanterhadap hak masyarakat dalam memperoleh informasi yang benar;

d. Asas efisiensi, yaitu pengelolaan barang milik daerah diarahkan agar barangmilik daerah digunakan sesuai batasan-batasan standar kebutuhan yang diperlukan dalam rangka menunjang penyelenggaraan tugas pokok dan fungsi pemerintahan secara optimal;

e. Asas akuntabilitas, yaitu setiap kegiatan pengelolaan barang milik daerahharus dapat dipertanggungjawabkan kepada rakyat;

f. Asas kepastian nilai, yaitu pengelolaan barang milik daerah harus didukungoleh adanya ketepatan jumlah dan nilai barang dalam rangka optimalisasipemanfaatan dan pemindahtanganan barang milik daerah serta menyusun neraca pemerintahan. Berdasarkan hasil analisis data, diketahui bahwa sistem pengelolaan aset tetap oleh Sekretariat Daerah Kabupaten Buton berpedoman pada Peraturan Menteri Dalam Negeri Nomor 17 tahun 2007 tentang sistem pengelolaan barang milik Negara/Daerah [10]. Berikut ini uraian sistem pengelolaan aset tetap yang terdapat pada Sekretariat Daerah Kabupaten Buton.

1. Perencanaan Kebutuhan dan Penganggaran

Sesuai dengan Peraturan Menteri Dalam Negeri Nomor 19 Tahun 2016 tentang Pedoman Pengelolaan Barang Milik Daerah Perencanaan kebutuhan dan penganggaransekretariat Kabupaten Buton dilakukan sebagai berikut :

a. Dalam melakukan perencanaan kebutuhan barang dilaksanakan berdasarkanpertimbangan yaitu:

1) untuk mengisi kebutuhan barang pada masing-masing Unit/Satuan Kerja sesuaibesaran organisasi/jumlah pegawai dalam satu organisasi; 
2) adanya barang-barang yang rusak, dihapus, dijual, hilang, mati atau sebab lainyang dapat dipertanggungjawabkan sehingga memerlukan penggantian;

3) adanya peruntukan barang yang didasarkan pada peruntukan standar perorangan, jika terjadi mutasi bertambah personil sehingga mempengaruhikebutuhan barang;

4) untuk menjaga tingkat persediaan barang milik daerah bagi setiap tahunanggaran bersangkutan agar efisien dan efektif; danpertimbangan teknologi.

b. Fungsi perencanaan penganggaran merupakan rangkaian kegiatan dalampemenuhan kebutuhan dengan memperhatikan kemampuan atau ketersediaankeuangan daerah;

c. Perencanaan penganggaran untuk pemenuhan kebutuhan barang harus terincidengan memuat banyaknya barang, nama barang, waktu dan jumlah biaya yangdiperlukan;

d. Perencanaan kebutuhan barang milik daerah disusun oleh masing-masing unitsesuai Rencana Kerja dan Anggaran Satuan Kerja Perangkat Daerah (RKA-SKPD)dengan memperhatikan standarisasi sarana dan prasarana kerja pemerintahandaerah dan standarisasi harga yang telah ditetapkan oleh Kepala Daerah;

e. Kegiatan Perencanaan Kebutuhan dan Penganggaran.Dalam perencanaan kebutuhan dan penganggaran pada sekretariat daerah kabupaten buton setiap tahun direncanakan oleh bendahara pengurus/penyimpan barang dengan menerima usulan dari setiap bidang. Masing-masing bidang mengusulkan rencana kebutuhan barang dan anggaran yang dibutuhkan untuk mengadakan barang tersebut ditahun yang akan datang.

2. Pengadaan

Pengadaan barang pada sekretariat daerah dilaksanakan berdasarkan usulan rencana kebutuhan barang dari setiap bidang. Usulan kebutuhan barang dari setiap bidang akan disesuaikan dengan anggaran yang tersedia. Jika kebutuhan barang melebihi anggaran yang disediakan maka akan diproritaskan barang yang menjadi kebutuhan urgen untuk mendukung operasional bidang, misalnya pengadaan alat tulis kantor, laptop dan printer. 
Tata cara pengadaan barang pada Sekretariat Daerah Kabupaten Buton dilaksanakan dengan cara :

a. Panitia Pengadaan ditetapkan dengan Surat Keputusan Kepala Daerah dengansusunan keanggotaannya melibatkan unsur teknis terkait;

b. Panitia pengadaan menyelenggarakan tender/lelang dan mengambil keputusandalam suatu rapat yang dituangkan dalam Berita Acara Lelang mengenai calon pemenang atas dasar harga terendah dikaitkan dengan harga perkiraan sendiri(owner estimate) yang dapat dipertanggungjawabkan untuk kualitas barang yangd ibutuhkan, selanjutnya menyampaikan Berita Acara tersebut disertai saran kepada Kepala Daerah dan/atau Sekretaris Daerah untuk menetapkan Pemenang Lelang.Dalam Berita Acara Lelang dimaksud memuat antara lain:

a) Hari, tanggal dan tempat pelaksanaan lelang;

b) Anggota panitia yang hadir;

c) rekanan yang diundang, rekanan yang hadir, rekanan yang memenuhisyarat; dan

d) surat-surat penawaran yang masuk.

c. Setelah ditetapkan calon pemenang lelang, Kepala Daerah atau pengelola atau pengguna, menetapkan pemenang lelang;

d. Pelaksanaan pengadaan/pekerjaan dilakukan dengan cara sebagai berikut:

a) Membuat Surat Perjanjian yang ditandatangani oleh Kepala Daerah ataupengelola atau Kepala SKPD;dan

b) Sepanjang pengadaan/pekerjaan tidak dilakukan melalui lelang, makapelaksanaan pengadaan/pekerjaan dilakukan dengan Surat Perintah Kerja yang ditandatangani oleh Kepala SKDP dan/atau pejabat pengadaan. Dalam Surat Perintah Pengadaan/Pekerjaan tersebut diatas merupakan dasaruntuk penerimaan barang, harus dengan tegas memuat dan menyatakanjumlah barang dan biaya maupun syarat-syarat lain yang diperlukan.

e. Penerimaan barang dilaksanakan oleh penyimpanan barang dan/atau pengurus barang setelah diperiksa oleh Panitia Pemeriksa Barang Daerah dengan membuat Berita Acara Pemeriksaan. 
f. Pembayaran hanya dapat dilakukan apabila dilampiri dokumen-dokumen sesuai dengan ketentuan yang berlaku.

\section{Penerimaan dan Penyaluran}

Bendahara pengurus/penyimpan barang Sekreatariat Daerah Kabupaten Buton akan menyalurkan kebutuhan barang yang sudah dibeli kepada setiap bidang sesuai dengan daftar yang tertulis dalam rencana kebutuhan barang.

4. Penggunaan

Penggunaan barang oleh setiap bidang adalah untuk mendukung kegiatan operasional setiap bidang, jika barang tersebut memiliki umur pemakaian diatas 1 (satu) tahun jika dibawa pulang kerumah pemakai maka harus dibuatkan berita acara peminjaman barang oleh bendahara pengurus/penyimpan barang yang ditandatangani oleh sekretaris daerah. Namun jika barang untuk kebutuhan masingmasing bidang yang memiliki umur pemakaian dibawah 1 (satu) tahun maka tidak dibuatkan berita acara peminjaman barang.

5. Penatausahaan

Penatausahaan adalah kegiatan bendahara pengurus/penyimpan barang sekretariat daerah kabupaten Buton dalam mencatat dan membukukan barang-barang yang sudah dibeli dalam buku inventaris barang, buku persediaan, kartu inventaris ruangan, kartu inventaris barang untuk memudahkan identifikasi pemakaian dan kepemilikan barang dari setiap bidang. Disamping itu penatausahaan juga dimaksudkan agar daftar barang milik sekretariat daerah tidak dipindahkan ketempat lain.

6. Pemanfaatan

Pemanfaatan barang milik daerah pada Sekretariat Daerah Kabupaten Buton disesuaikan dengan permintaan masing-masing bidang dan harus digunakan oleh bidang yang bersangkutan dan tidak boleh dimanfaatkan oleh bidang lain. Jika ada bidang lain yang akan memanfaatkan barang tersebut harus mendapatkan izin dari bidang yang memiliki barang dan dibuatkan nota pinjaman barang.

7. Pengamanan dan Pemeliharaan

Pengurus/penyimpan barang pada Sekretariat Daerah Kabupaten Buton memiliki tugas utama dan bertanggung jawab penuh terhadap pengamanan barang milik daerah yang terdapat pada sekretariat dengan selalu melakukan pemeriksaan rutin pada setiap bidang yang memiliki barang. Sedangkan pemeliharaan dilakukan oleh 
bendahara pengurus/penyimpan barang dengan mengusulkan anggaran pemeliharaan setiap tahun untuk pemeliharaan rutin dan penggantian suku cadang.

8. Penilaian

Penilaian barang pada sekretariat daerah dimaksudkan untuk menyusun neraca sekretariat daerah yang dilaksanakan setiap tahun sehingga dapat diketahui berapa jumlah aset pada sekretariat daerah setiap tahunnya.

9. Penghapusan

Bendahara pengurus/penyimpan barang pada sekretariat daerah tidak memiliki kewenangan untuk menghapus barang milik daerah pada sekretariat daerah, namun bendahara pengurus/penyimpan barang hanya melaksanakan membuat usulan penghapusan barang rusak atau sudah tidak dapat dimanfaatkan lagi oleh setiap bidang.

10. Pemindahtanganan

Bendahara pengurus/penyimpan barang pada sekretariat daerah kabupaten Buton membuat surat keterangan pinjam pakai, atau berita acara serah terima barang apabila terdapat barang pada sekretariat daerah yang digunakan oleh Satuan Kerja Perangkat Daerah lain dalam lingkup pemerintah kabupaten Buton.

11. Pembinaan, Pengawasan dan Pengendalian

Bendahara pengurus/penyimpan Barang Sekretariat Daerah Kabupaten Buton atas perintah sekretaris daerah melaksanakan pemantauan terhadap pemakaaian dan pemanfaatan barang milik daerah yang terdapat pada sekretariat daerah kabupaten Buton, jika ada barang milik daerah yang sudah dipindahtangankan atau dimanfaatkan oleh pegawai diluar lingkup sekretariat daerah maka bendahara pengurus/penyimpan barang melaporkan kepada sekretaris daerah untuk dibuatkan surat teguran dan surat penarikan atas barang tersebut.

12. Pembiayaan

Bendahara pengurus/penyimpan barang milik daeah mengusulkan anggaran pembiayaan atas barang milik daerah yang terdapat pada sekretariat daerah melalui anggaran pendapatan dan belanja daerah setiap tahun. Alokasi anggaran disediakan untuk penggantian suku cadang, pemeliharaan, pengisian bahan bakar, dan lainlain. 


\section{Tuntutan Ganti Rugi}

Bendahara pengurus/penyimpan barang sekretariat daerah dapat mengajukan ganti rugi terhadap barang milik daerah yang terdapat pada sekretariat daerah yang diakibatkan oleh kelalaian pengguna barang milik daerah disesuaikan dengan tingkat kerusakan barang terhadap pengguna barang milik daerah.

\section{KESIMPULAN}

Berdasarkan analisis yang dilakukan diatas maka dapat ditarik kesimpulan bahwa pengelolaan aset tetap pada Sekretariat Daerah Kabupaten Buton telah dilakukan dengan berpedoman pada Peraturan Menteri Dalam Negeri Nomor 19 Tahun 2016 tentang Pedoman Pengelolaan Barang Milik Daerah. Hal ini dapat dilihat dari pelaksanaan siklus perencanaan dan penganggaran, pengadaan, penggunaan, pemanfaatan, pengamanan dan pemeliharaan, penilaian, pemindahtanganan, pemusnahan, penghapusan, penatausahaan, serta pembinaan, pengawasan, dan pengendalian.

\section{SARAN}

Penelitian ini masih memiliki keterbatasan dan kekurangan mengingat analisis yang digunakan ialah analisis deskriptif kualitatif dari hasil wawancara dan analisis dokumen. Untuk itu, bagi peneliti selanjutnya diharapkan melakukan penelitian serupa dengan metode analisis dan pengumpulan data yang berbeda.

\section{DAFTAR PUSTAKA}

[1] Martani, Dwi, dkk. 2016. Akuntansi Keuangan Menengah Berbasis PSAK Buku 1. Jakarta: Salemba Empat.

[2] Republik Indonesia. Peraturan Pemerintah Nomor 71 Tahun 2010 tentang Standar Akuntansi Pemerintahan.

[3] Baridwan, Zaki. 2008. Intermediate Accounting. Yogyakarta: BPFE UGM

[4] Ikatan Akuntan Indonesia. 2011. PSAK Nomor 16: Aset Tetap Revisi (2011).

[5] Komite Standar Akuntansi Pemerintahan. 2007. Buletin Teknis SAP Nomor 5: Akuntansi Penyusutan.

[6] Republik Indonesia. Peraturan Pemerintah Nomor 27 Tahun 2014 tentang Pengelolaan Barang Milik Negara/Daerah.

[7] Auditor General for Local Government Perspectives. 2015. Asset Management For Local Governments. Diakses pada 20 November2018 dari: https://www.ubcm.ca/assets/Funding Programs/Asset Management/AGLGAMForLo calGovernments.pdf 
[8] Atikoh,N., E. Febrian, dan R. Hendrawan. 2017. Fixed Asset Management in The Indonesian Government Agencies: A Case Study At Ministry Of Trade. International Journal of Economics, Commerce and Management. Vol. V (12): 674 - 694

[9] Indriantoro, Nur. 2009. Metodologi Penelitian Bisnis. Edisi Pertama. Yogyakarta: BPFE UGM.

[10] Republik Indonesia. Peraturan Menteri Dalam Negeri Nomor 19 Tahun 2016 tentang Pedoman Pengelolaan Barang Milik Daerah. 